\title{
FIRST CASE OF ENDOVASCULAR TREATMENT OF RUPTURED INTERNAL CAROTID ARTERY ANEURYSM USING STENT ASSISTED COILING AT THE DEPARTMENT OF NEUROSURGERY IN SKOPJE
}

\author{
Venko Filipce, Aleksandar Caparoski, Zoran Milosevic \\ University Department of Neurosurgery in Skopje, R. Macedonia \\ Corresponding Author: Venko Filipce, University Department of Neurosurgery in Skopje, R. Macedonia; \\ Tel: +389 (0)2 070334333 E-mail: venkofilipce@yahoo.com;
}

\begin{abstract}
The management of intracranial aneurysms has changed dramatically in recent years. The science and technology advancement have resulted in new therapeutic options for their treatment. There is an increased interest among neurosurgeons to perform endovascular procedures for intracranial aneurysms. This has become a part of the neurosurgical residency in the US. We are presenting our first experience of ruptured aneurysm coiling using stent assisted technique.
\end{abstract}

Key words: ruptured cerebral aneurysm, stent assisted coiling

\section{Introduction}

The management of intracranial aneurysms has changed dramatically in recent years. The science and technology advancement have resulted in new therapeutic options for their treatment. The endovascular treatment of intracranial aneurysms has evolved as a result of a continuous ongoing process in the field of neuroscience. Its safe application and now perfect results are possible due to the safety of the devices available, better imaging modalities of the new technology, and improved knowledge of the underlying disease process $[3,4,14]$.

The enthusiasm of Guido Guglielmi, a neurosurgeon from Italy, led to introducing the platinum coil, eventually leading to the development of the detachable coil [14]. His work in the early 1980s with the assistance of Ivan Sepetka, an engineer at Target Therapeutics, Inc., led to combined endovascular electrolysis with electrothrombosis to develop the currently used Guglielmi detachable coil (Boston Scientific/Target Therapeutics, Fremont, CA) [3, 4, 14].

Recently, endovascular neurosurgery has gained a great interest along with the advance- ment of the modern neurosurgery. The most remarkable advances were made in embolization of the cerebral aneurysms, arteriovenous malformations and other vascular malformations in the past 10 years. These advances will further change the role of neurosurgeons in treating cerebrovascular disease [15].

\section{Case Report}

At the Department of Neurosurgery in Skopje, 56-year old patient was admitted due to subarachnoid hemorrhage at the day of admission. The neurological status was evaluated according to the Glasgow Coma Scale -15 and Hunt and Hess scale -2, i.e. conscious, with headache, nausea and stiff neck. No focal neurological deficit was present. The initial CT scan showed subarachnoid hemorrhage and the CT angiography revealed a left ICA aneurysm at the level of PCom with wide neck. The patient was treated in a delayed manner, two weeks after the admission. One day before the treatment a loading dose of double antiaggregation therapy was administered. An endovascular procedure was conducted, it started with a 
puncture in the right groin, introduction of a $6 f$ sheet. Afterwards, 4 vessels angiography was performed, a 6 f Envoy mpc catheter was placed in the left ICA. Using microcatheter (J\&J Prowler Select Plus 150 str) and microwire (J\&J Neurscout 14 standard) position distal to the neck of the aneurysm was achieved and stent $(\mathrm{J} \& \mathrm{~J}$ Enterprise $4.5 \times 22 \times 12$ ) was placed over the neck of the aneurysm. Then, the aneurysm was coiled using the standard technique (J\&J Deltaplush and Deltapaq coils) (Figure 1-5). The Procedure was performed by the first author under supervision of the third author. No complications occurred. The patient was awakened without neurological deficit. Double antiaggregation therapy was prescribed to the patient in a period of 3 months following the procedure.

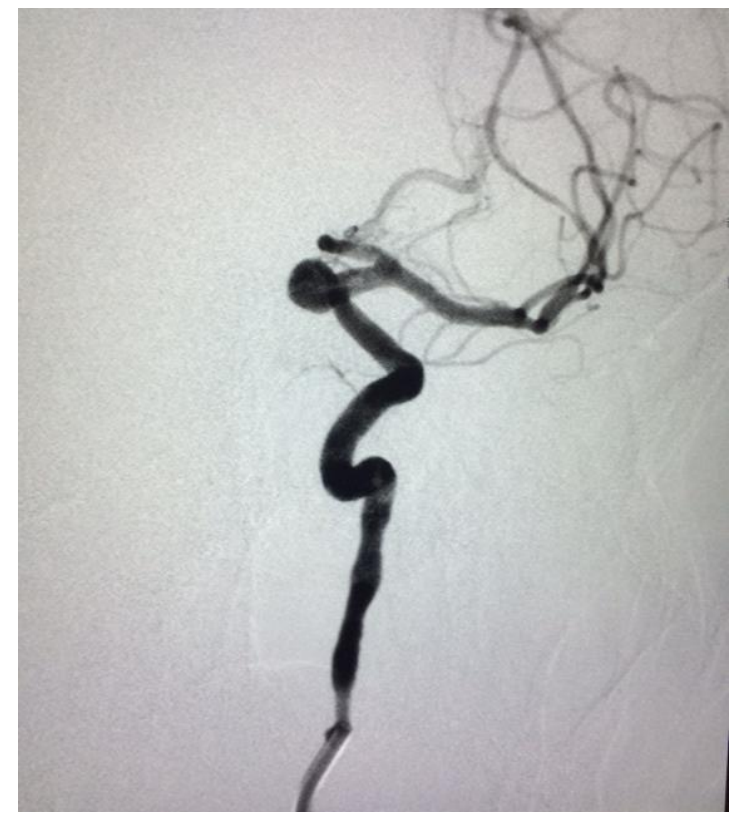

Figure 1-Angiographic view of the aneurysm

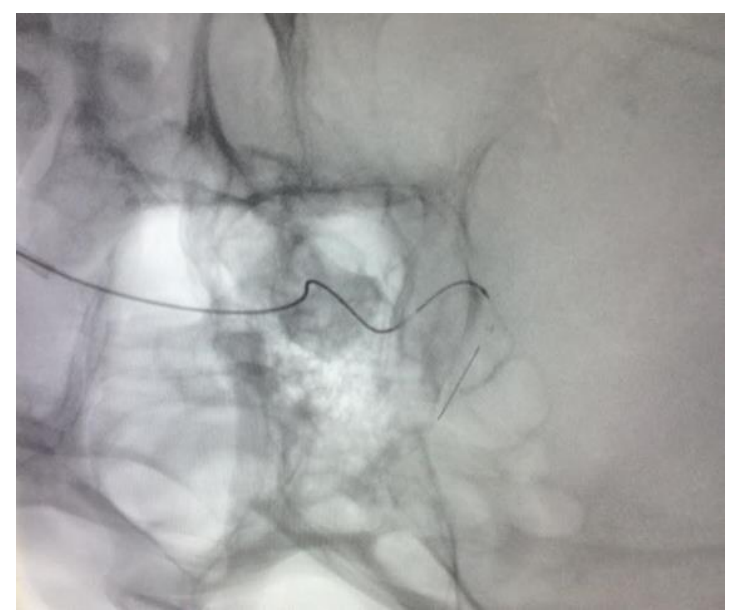

Figure 2 - Placing the stent

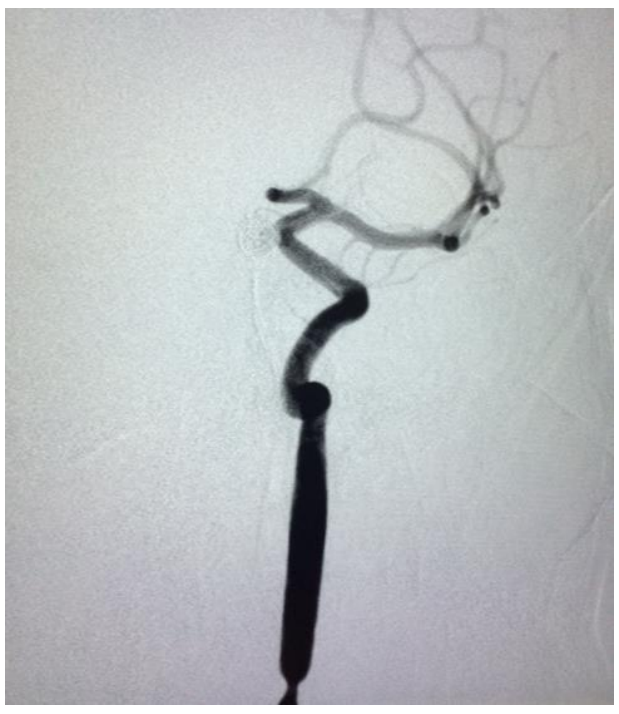

Figure 3 - Coiling through placed stent

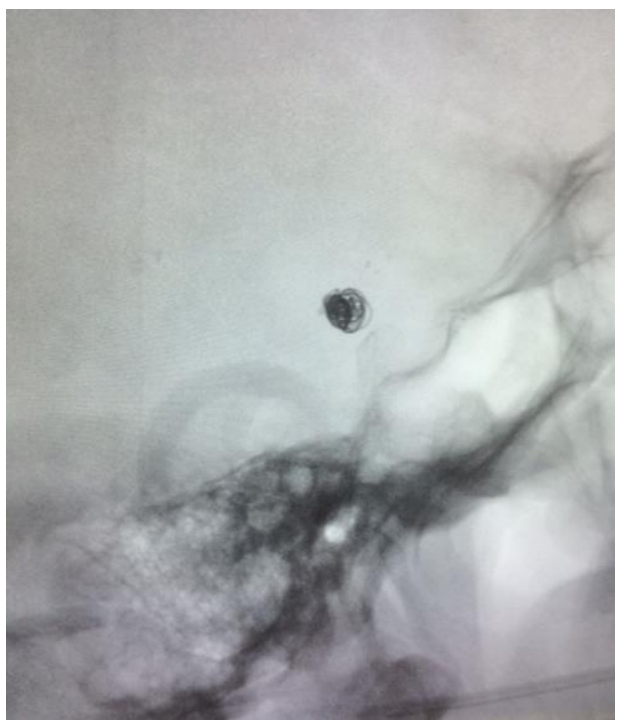

Figure 4 - View of coiled aneurysm

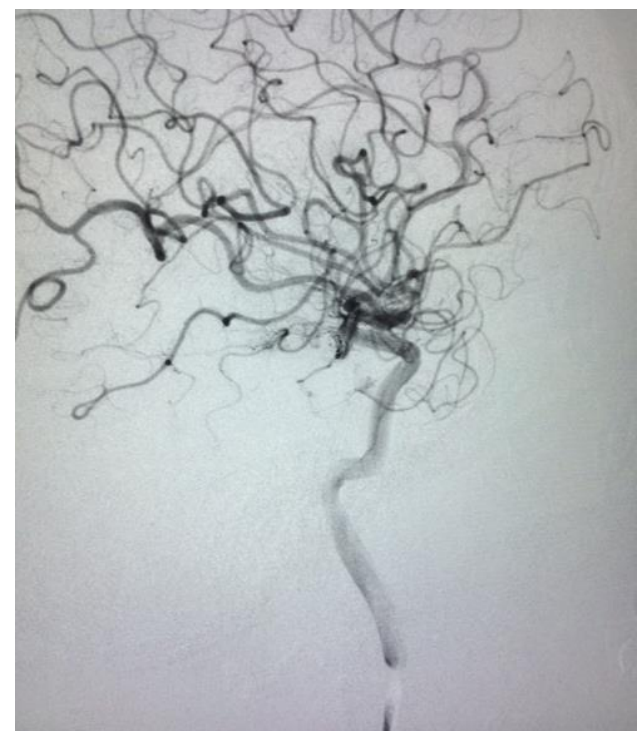

Figure 5-Angiographic view of the carotid artery after the finished procedure 


\section{Discussion}

The interest in the endovascular techniques for the treatment of intracranial aneurysms has exploded in the past decade $[6,10$, 14]. Although considered a second-line treatment not so far ago, it has become primary therapeutic option at some centers $[1,7]$. It is also favorable by patients as small groin incision procedure is accepted and is considered as "minimally invasive", avoiding craniotomy for treatment. The aim of the treatment is occlusion and thrombosis of the aneurysm sac. There are two established techniques, depending on the strategy, one being, the so called deconstructive, which means occlusion of the parent vessel and its aneurysm, or reconstructive, which involves selective obliteration of the aneurysm and sparing the parent artery. Stent assisted coiling is used to increase the density of the aneurysm packing while the stent prevents coil herniation into the lumen of the vessel and prevents eventual consecutive parent vessel obliteration. A study performed by Vanninen and Co [13] in 1999, compared the endovascular versus surgical treatment of ruptured intracranial aneurysms in the first 72 hours of hemorrhage. 52 patients were treated endovascularly and 57 surgically. Two groups were matched for age, sex, H\&H grade, Fisher grade and site or size of the ruptured aneurysm. There were no differences in 3 months clinical outcomes evaluated by Glasgow Outcome Scale, i.e. $81 \%$ of the endovascular and $79 \%$ of the surgically treated patients had good or moderate recovery. Also, no differences in neuropsychological outcome were observed between two groups (there is no brain retraction in endovascular group) [13]. The patients in the surgical group had more ischemic lesions in the parent artery territory of the ruptured aneurysm.

\section{Conclusion}

In our experience, the endovascular treatment is an excellent method for intracranial aneurysm treatment and should be further developed as alternative to aneurysm coiling. It is better accepted by the patients and considered as minimally invasive method. Also, it dec- reases the hospital stay and eliminates possible complications that might occur from craniotomy.

\section{REFERENCE}

1. Cognard C, Weill A, Castaings L, et al: Intracranial berry aneurysms: NAgiographic and clinical results after endovascular treatment. Radiology 206: 499$510,1998$.

2. Guimond JG, Chagnon PM, Bojanowski MW. Clipping vs. coiling in acute aneurysmal subarachnoid haemorrhage: Should the patient's medical condition influence treatment modality? Neurochirurgie. 2012 Apr-Jun; 58(2-3): 115-24.

3. Guglielmi G, Viñuela F, Dion J, et al: Electrothrombosis of saccular aneurysms via endovascular approach. Part 2: preliminary clinical experience. J Neurosurg. 75: 8-14, 1991.

4. Guglielmi G, Viñuela F, Sepetka I, et al: Electrothrombosis of saccular aneurysms via endovascular approach. Part 1: electrochemical basis, technique, and experimental results. J Neurosurg. 75: 1-7, 199120. Hieshima GB, Higashida.

5. Konczalla J, Platz J, Brawanski N, Güresir E, Lescher S, Senft C, du Mesnil de Rochemont R, Berkefeld J, Seifert V. Endovascular and surgical treatment of internal carotid bifurcation aneurysms: comparison of results, outcome, and mid-term follow-up. Neurosurgery. 2015 May; 76(5): 540-50.

6. Lad SP, Babu R, Rhee MS, Franklin RL, Ugiliweneza $\mathrm{B}$, Hodes $\mathrm{J}$, et al. Long-term economic impact of coiling vs clipping for unruptured intracranial aneurysms. Neurosurgery. 2013 Jun; 72(6): 1000-11.

7. Lot G, Houdart E, Cophignon J: Combined management of intracranial aneurysms by surgical and endovascular treatment: Modalities and results from a series of 395 cases. Acta neurochir (Wien). 1999; 141: 557-562.

8. Mutoh T, Kazumata K, Yokoyama Y, Ishikawa T, Taki Y, Terasaka S, Houkin K. Comparison of postoperative volume status and hemodynamics between surgical clipping and endovascular coiling in patients after subarachnoid hemorrhage. J Neurosurg Anesthesiol. 2015 Jan; 27(1): 7-15.

9. Park KY, Kim BM, Lim YC, Chung J, Kim DJ, Joo JY, et al. The role of endovascular treatment for ruptured distal anterior cerebral artery aneurysms: 
comparison with microsurgical clipping. J Neuroimaging. 2015 Jan-Feb; 25(1): 81-6.

10. Ruan C, Long H, Sun H, He M, Yang K, Zhang H, Mao B. Endovascular coiling vs. surgical clipping for unruptured intracranial aneurysm: A meta-analysis. Br J Neurosurg. 2015; 29(4): 485-92.

11. Sekhar LN, Tariq F, Morton RP, Ghodke B, Hallam DK, Barber J, Kim LJ. Basilar tip aneurysms: a microsurgical and endovascular contemporary series of 100 patients. Neurosurgery. 2013 Feb; 72(2): 284-98.

12. Shakir HJ, Levy EI. The blunt truth behind coiling vs clipping: consumers as decision-drivers. Neurosurgery. 2014 Jan; 74(1): E145-6.

13. Vanninen R, Koivisto T, Saari T, Ruptured intracranial aneurysms: Acute endovascular treatment with electroliticalkly detachable coils-a prospective randomized study. Radiology. 1999; 211: 325-336.

14. Yassine Kanaan, BS, David Kaneshiro, BS, Kenneth Fraser, MD, David Wang, DO, and Giuseppe Lanzino, MD: Evolution of endovascular therapy for aneurysm treatment, Neurosurgical Focus Feb 2005 / Vol. 18 / No. 2, Pages 1-4.

15. Young Il Jeon, M.D. and Do Hoon Kwon, M.D.: Current Status and Future Prospect of Endovascular Neurosurgery: J Korean Neurosurg Soc. 2008 Feb; 43(2): 69-78
Резиме

ПРВ СЛУЧАЈ НА ЕНДОВАСКУЛАРЕН ТРЕТМАН НА РУПТУРИРАНА АНЕВРИЗМА НА АРТЕРИЈА КАРОТИС ИНТЕРНА КОРИСТЕЈК'И СТЕНТ АСИСТИРАЧКИ КОИЛИНГ НА КЛИНИКАТА ЗА НЕВРОХИРУРГИЈА ВО СКОПЈЕ

\section{Венко Филипче, Александар Чапароски, Зоран Милошевиќ}

Универзитетска клиника за неврохирургија, Скопје, Р. Македонија

Третманот на интракранијалните аневризми значајно се промени во изминатите години, пред сѐ, со развојот на новата технологија. Постои зголемен интерес кај неврохирурзите во светот за ендоваскуларните процедури кај интракранијалните аневризми. Ендоваскуларната неврохирургија стана составен дел од специјализацијата по неврохирургија во САД. Во овој труд го презентираме нашето прво искуство во ендоваскуларниот третман на руптурираните интракранијални аневризми.

Клучни зборови: руптирана интрацеребрална аневризма, стент асистирачки коилинг 